\title{
Psycho-social problems in patients with 22q11.2 deletion syndrome - according to subjective evaluation by parents
}

\author{
AGNIESZKA CYWIŃSKA-BERNAS 1, 2, A, B, D-F , JAROSŁAW PAŚNIK ${ }^{1,2, ~ B, ~ E, ~}$

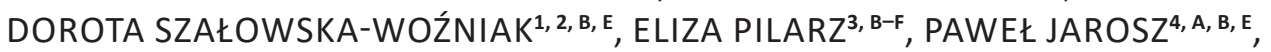 \\ MAŁGORZATA PIOTROWICZ5, A, B, AGNIESZKA MOLL-MARYŃCZAK ${ }^{1, A, B, E}$, \\ MARCIN MACHNIA ${ }^{3, D, E}$, KRZYSZTOF ZEMAN ${ }^{1,2, A, ~ D, ~ E, ~ G ~}$
}

\author{
${ }^{1}$ Department of Pediatrics, Preventive Cardiology and Immunology of Developmental Age, Medical University, \\ Lodz, Poland \\ ${ }^{2}$ Department of Pediatrics, Immunology and Nephrology, Polish Mothers' Memorial Hospital Research Institute, \\ Lodz, Poland \\ ${ }^{3}$ Department of Rehabilitation, Polish Mothers' Memorial Hospital Research Institute, Lodz, Poland \\ ${ }^{4}$ Department of Nephrology, Hypertension and Family Medicine, Military Medical Academy University Teaching \\ Hospital - Central Veterans' Hospital, Lodz, Poland \\ ${ }^{5}$ Department of Genetics, Polish Mothers' Memorial Hospital Research Institute, Lodz, Poland
}

A - Study Design, B - Data Collection, C - Statistical Analysis, D - Data Interpretation, E - Manuscript Preparation, F - Literature Search, G - Funds Collection

Summary Background. Deletion syndrome 22q11.2 is a frequently occurring genetic disorder effecting not only malfunctions of the structure and function of many organs and systems, but also a number of psycho-social problems in patients of all ages.

Objectives. The aim of the study was the evaluation of psycho-social problems experienced by people with confirmed 22q11DS observed by their parents/caregivers.

Material and methods. A group of 32 parents'/caregivers' children with 22q11DS diagnosis (confirmed by FISH or MLPA analysis) were examined. The age of patients at the moment of examination was from 3 months to 23 years. To identify the most frequent problems a questionnaire survey was used with the use of the authors' questionnaire.

Results. On the basis of the acquired data analysis it was stated that the most frequent problems in children reported by the questioned parents/caregivers were problems with speech development, problems with focusing attention, problem in relations with peers, and school difficulties. The questioned parents also emphasized excessive anxiety of the children and frequent behavior disorders. Moreover, many parents are concerned with their children's adult lives, and emphasize the necessity of professional support (including psychological) in different stages of the sick child's upbringing.

Conclusions. Patients with 22q11DS experience many psychological and social problems and require, with their families, psychological support in different stages of life. The child's condition, in many parents' opinion, is a factor significantly influencing functioning in life and determining the occurrence of problems in the future. The task of primary care physicians is not only to identify patients suspected of 22q11DS and to lead them to genetic diagnostics, but also to provide support to the patients and their families in different stages of life in cooperation with many other specialists.

Key words: 22q11 deletion syndrome, behavior, psychology, child, parents.

Cywińska-Bernas A, Paśnik J, Szałowska-Woźniak D, Pilarz E, Jarosz P, Piotrowicz M, Moll-Maryńczak A, Machnia M, Zeman K. Psycho-social problems in patients with 22q11.2 deletion syndrome - according to subjective evaluation by parents. Fam Med Prim Care Rev 2018; 20(2): 117-123, doi: https://doi.org/10.5114/fmpcr.2018.76453.

\section{Background}

22q11 deletion syndrome (22q11DS) is a chromosomal anomaly, occurring in at least 1 per 4,000 newborns. It affects the health of patients and the quality of their life, starting with birth, then continuing in infancy, childhood and adulthood [1]. The anomaly is made up of more than 180 features and defects, not only physical, but also those regarding social functioning or psychological aspects. A high incidence of congenital heart disease, concomitant disturbances in the calcium-phosphate metabolism, dysfunction in the immune system, subtle dysmorphic facial features, as well as a high incidence of communication disturbances and typical cognitive and behavioral profile are distinct characteristics observed in people affected by 22q11DS [2]. Characteristic facial dysmorphia (long narrow face, almond shaped eyes, a bulbous nose, small mouth, folded over ear helix) in one of our patients (in infant and toddler age) is presented in photographs (Photos 1, 2). Parental written consent was obtained for the publication of the child's photos.

A clinically suspected case of deletion syndrome can nowadays be confirmed in genetic tests, performed with the application of FISCH (fluorescent in situ hybridization) or MLPA (Multiplex Ligation-dependent Probe Amplification) techniques. The TBX1 gene, controlling the development of structures of the third and fourth pharyngeal poaches, is located in the deletion area. Inactivation of this gene might contribute to the occurrence of cleft palate and/or velopharyngeal insufficiency, hypoparathyroidism, leading to hypocalcemia, and also congenital diseases of the cardiac system (confirmed in 50-85\% of patients) [3]. Lack of the thymus or thymic hypoplasia, typi- 


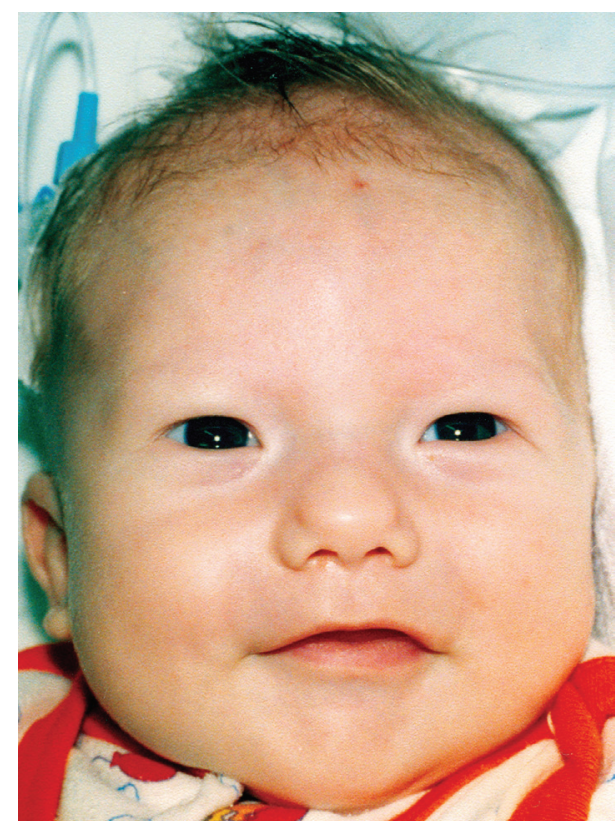

Photo 1. Facial dysmorphia infant with 22q11.2

cal for DiGeorge syndrome, result from immune disturbances, manifesting mainly with an insufficient number and impaired function of T cells, as well as an increased risk of diseases depending on proper functioning of the immune system, such as autoimmune processes or neoplasia. The risk of such diseases grows with age. Other anomalies typical for 22q11DS include disturbances of the genitourinary system, developmental disturbances of the pituitary, and skeletal malformations $[2,4$, 5]. Besides, due to the effect of microdeletion on the central nervous system (other genes, localized in the critical region are responsible for that) such patients demonstrate certain behavioral and cognitive anomalies, as well as mental disturbance. They are also more frequently affected by epilepsy/seizures and schizophrenia $[1,2,6,7]$. Developmental and learning problems are also common in childhood [1, 2, 7-9].

It is also possible today to accurately identify and describe the microdeletion subtypes (proximal, central, distal with 3 types) due to modern techniques (genomic microarrays), and the latest publications show the phenotypic phenomena that are very broadly expressed, even among families [10].

The fact that in the Polish professional literature there are not many detailed studies on psycho-social problems in patients with the above genetic syndrome, as well as the fact that many disturbances which are typical for 22q11DS are easily observed by those who provide such patients with daily care, made us plan and conduct a pilot study on the incidence of these disturbances in patients affected by 22q11DS who are looked after in our department. It is beyond any doubt that all chronic diseases, malformations, damage or disturbances limit to some extent the patient's self-reliance and his/her social functioning [11-13].

\section{Objectives}

The aim of the study was to identify and evaluate the most common psychological problems and social dysfunctioning of patients affected by 22q11 deletion syndrome, confirmed in genetic examinations.

\section{Material and methods}

The pilot study involved 32 parents/guardians of patients with 22q11DS, who stayed in the Department of Pediatrics,

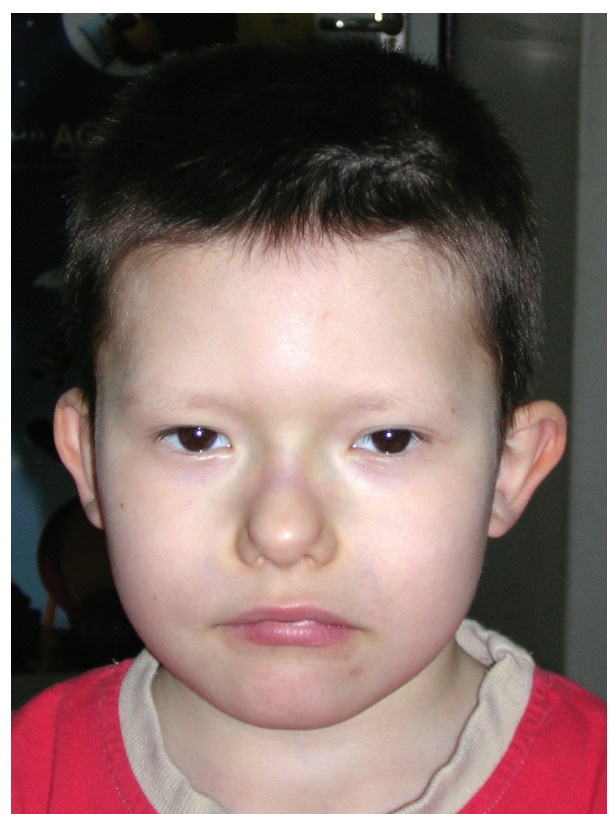

Photo 2. Facial dysmorphia child with 22q11.2

Immunology and Nephrology of the Polish Mothers' Memorial Hospital Research Institute in Lodz, between May 2015 and June 2016. The study was conducted with the application of the survey method. The authors used their own questionnaire regarding psycho-social problems of the patients with 22q11DS observed by family members, with particular consideration given to learning, developmental, emotional and social problems. The questionnaire consists of 58 questions (open-ended and close-ended) which in the first part (questions 1-11) includes data related to the child, the parent filling out the questionnaire, some demographic information, and family structure, with no identifiable data (anonymous). Other questions relate information about child development and its disorders, school and social problems, psychological and/or psychiatric care, and also some disturbing symptoms and/or abnormal behavior which was observed by parents. Because of the pilot character of the study and the use a set of well-known questions that parents can understand, the questionnaire was not validated by special principles of questionnaire validation.

The parent/guardian accompanying the patient during his/ /her hospitalization/visit to the department was asked to fill in the questionnaire. 22q11 deletion syndrome, confirmed in genetic examinations, and written informed consent, signed by the patient's parent/guardian and by the patient himself/herself if he/she was 16 years of age after getting familiar with the aim and course of the study, were required so that the patient could be included in the study. The Bioethics Committee of the Medical University of Lodz (21 April, No. RNN/105/15/KE) and the Bioethics Committee of the Polish Mothers' Memorial Hospital Research Institute in Lodz (14 April 2015, No. 26/2015) gave consent for the study to be conducted.

Among the respondents there were 30 females and 2 males; the mean age of the respondents was 36 years. In the study period the age of the patients ranged from 3 months to 23 years. The study group consisted of 18 female patients ( 16 girls and 2 adults) and 14 boys. Table 1 presents detailed characteristics of the study group and information on the respondents (people filling in the questionnaire).

Most of the patients (78\%) were raised by both parents, 4 $(12.5 \%)$ were raised by one parent, only 2 were brought up in a reconstituted family, and in one case it was single-intended parenthood. Of the families included in the study, only 7 (22\%) lived in the countryside; the remaining ones (78\%) lived in various-sized towns. Thirteen parents/guardians claimed their 
economic situation to be very good or good, and another 13 considered the situation satisfactory (in total $81 \%$ ). Six parents/ /guardians (19\%) considered their situation to be unsatisfactory.

Among the patients studied we found almost all the characteristic for 22q11DS features. Congenital heart defect was confirmed in 25 cases from the study group (78\%). The most common anomalies were tetralogy of Fallot ( 8 of them) and interrupted aortic arch (in 6 patients). Palatal anomalies were also very common. Cleft palate (in most cases submucous) was found in 14 patients (43\%). T lymphocyte immunodeficiency was observed in 12 patients (37\%) during any period of their life. Many of our patients (25 individuals, 78\%) suffered from recurrent respiratory tract infection. Hypocalcemia due to hypoparathyroidism was seen in 7 patients (21\%), and other endocrine disorders that we observed in the study group were hypothyroidism - in 9 children (28\%) and growth hormone deficiency in 2 teenage patients. Failure to thrive was seen in $8(25 \%)$ small children, but constipation was very popular problem in all age groups and concerned 20 (62\%) of studied patients. The above clinical characteristics of the studied patients were identified using medical data, but not parents' answers in the questionnaire.

\begin{tabular}{|c|c|}
\hline Trait & Number/value \\
\hline $\begin{array}{l}\text { Sex of the parent/guardian } \\
\text { - women } \\
\text { - men }\end{array}$ & $\begin{array}{l}30(94 \%) \\
2(6 \%)\end{array}$ \\
\hline $\begin{array}{l}\text { Parent's age on the day of the } \\
\text { study }\end{array}$ & $\begin{array}{l}\text { mean } 36 \text { years of age (from } 21 \\
\text { to } 56 \text { ) }\end{array}$ \\
\hline $\begin{array}{l}\text { Sex of the patient: } \\
\text { - girls } \\
\text { - boys }\end{array}$ & $\begin{array}{l}18(56 \%) \\
14(44 \%)\end{array}$ \\
\hline $\begin{array}{l}\text { Patient's age on the day of the } \\
\text { study } \\
\text { - infants } \\
-2-3 \text { years of age } \\
\text { - kindergarten } \\
- \text { school } \\
->18 \text { years of age } \\
\end{array}$ & $\begin{array}{l}\text { mean } 7 \text { years } 11 \text { months (from } \\
3 \text { months to } 23 \text { years of age) } \\
8(25 \%) \\
4(12.5 \%) \\
4(12.5 \%) \\
14(44 \%) \\
2(6 \%)\end{array}$ \\
\hline $\begin{array}{l}\text { Family structure: } \\
\text { - two-parents } \\
\text { - single-parent and single- } \\
\text {-intended } \\
\text { - reconstituted }\end{array}$ & $\begin{array}{l}25(78 \%) \\
5(16 \%) \\
2(6 \%)\end{array}$ \\
\hline $\begin{array}{l}\text { Family's living place: } \\
\text { - town }>50,000 \text { inhabitants } \\
\text { - town } 10-50,000 \text { inhabitants } \\
\text { - town }<10,000 \text { inhabitants } \\
\text { - village }\end{array}$ & $\begin{array}{l}8(25 \%) \\
12(37 \%) \\
5(16 \%) \\
7(22 \%)\end{array}$ \\
\hline $\begin{array}{l}\text { Family's economic situation: } \\
\text { - very good or good } \\
\text { - satisfactory } \\
\text { - unsatisfactory }\end{array}$ & $\begin{array}{l}13(41 \%) \\
13(41 \%) \\
6(18 \%)\end{array}$ \\
\hline
\end{tabular}

\section{Results}

Answers given by 32 parents/guardians of patients with 22q11DS were analyzed for the purpose of the study.

More than half the parents/guardians (about 60\%) visited the outpatient clinic or hospital more than 6 times within a year. In the school aged children group it was $46 \%$ of families.

24 parents/guardians from the studied group, which amounts to $75 \%$ (and 11 from $14-78 \%$ school aged children group), claimed that the disease restricts the daily functioning of their child. In 12 cases the limitations related to learning problems, and in 15 to social problems with peers. In single cases the problems were related to disturbances of physical development, muscle tone and attention deficit.

Only two children, in the infancy and post-infancy period, attended a nursery, and 17 ( $73 \%$ aged $3-6$ years) attended a kindergarten.

All 14 children who were of school age attend school. The majority of them go to mainstream schools or integrated schools; two children attend school for children with special needs, one child attends a vocational school, and one is enrolled in a life skills class. $36 \%$ children repeated a grade. Parents point out that Mathematics and the Polish language (mainly reading, writing, articulation) cause learning problems in $86 \%$ of children. Besides, parents report difficulty in performing activities requiring manual dexterity, and acquiring knowledge of Chemistry, Informatics and Physics. Only 2 studied children of school age (14\% of this subgroup) did not report any learning problems.

A considerable number of children manifest problems with speech development. All the studied children who were older than one year demonstrated inhibited speech development. In many cases this inhibition is manifested by delayed development of active speech or with slurred speech with a nasal tone.

Another problem reported by parents is attention deficit (90\% in the whole group and $78 \%$ in school age children). Nineteen out of 21 children (90\%) demonstrate problems with peer contacts. In the school age children group $78 \%$ of them have these types of problems.

Other problems mentioned by parents include excessive apprehension (61\% in general and $71 \%$ in school age children), and also other behavioral problems like obstinacy and noisiness, which were seen in $43 \%$ of children. Almost half the children $(43 \%)$ who meet age criteria tend to withdraw from social contacts. It seems to be less frequent in older children - only $28 \%$ during attending school. In 8 cases parents claim that their children have problems with eye contact - and the occurrence of this problem is similar in general and the school age group ( $33 \%$ vs $35 \%$ ). Only 5 children (22\%) have a tendency to isolate from others. Besides, parents can also observe in their children alarmingly weird (in their subjective opinion) behaviors: pica-type disorders, stereotypies and tics, which means $15 \%$ or less, but self-destructive behaviors like picking scabs or lips (not cutting the skin) were seen in $18 \%$ of children. Two studied patients older than 6 years had suicidal thoughts, which means $10 \%$ of this age group, but neither has made any suicide attempt so far. Two out of 25 parents (8\%) considered their children sad. None of the studied children demonstrated any delusions, hallucinations or mutism.

The parents were also asked about the future of their children. Twenty two parents (69\%) claim that due to the disease the daily life of their children will be limited to certain extent. The children's parents most fear for their social contacts with peers ( 12 respondents $-37.5 \%$ ), learning problems ( 7 respondents $-22 \%)$, approval of their appearance (2 respondents $-6 \%)$, work (2 respondents $-6 \%$ ). Single respondents think that the child will not be self-reliant and his/her memory will be impaired. One parent could not exactly specify what problems the child will face. Only 7 out of 32 parents/guardians (22\%) believe that the disease will not have negative future implications.

Table 2 presents all problems related to learning, social functioning, as well as psychological disturbances occurring in the studied children and reported by their parents/guardians on the day of filling in the questionnaire. They are ranked according to the frequency of occurrence in the study group.

Despite numerous disturbances, concomitant psychosocial and educational problems affecting the functioning of the studied patients, only 24 (75\%) sought psychological help. Developmental milestone was confirmed in 9 children; 6 were diagnosed with intellectual disability (including $3-$ mild and 1 - moderate). Developmental delay was confirmed in 4 children, and in 1 child the development was below the developmental 


\begin{tabular}{|c|c|c|c|c|}
\hline Problem observed & Yes & No & Child too young & No answer \\
\hline $\begin{array}{l}\text { Speech development problems } \\
\text { delayed speech development, slurred speech }\end{array}$ & $100 \%(24 / 24)$ & $0 \%(0 / 24)$ & 6 & 2 \\
\hline Attention deficit & $90 \%(19 / 21)$ & $10 \%(2 / 21)$ & 11 & - \\
\hline Problems with peers & $90 \%(19 / 21)$ & $10 \%(2 / 21)$ & 10 & 1 \\
\hline Learning problems & $86 \%(12 / 14)$ & $14 \%(2 / 14)$ & 18 & - \\
\hline Excessively apprehensive child & $61 \%(16 / 26)$ & $39 \%(10 / 26)$ & - & 6 \\
\hline Behavioral problems & $43 \%(10 / 23)$ & $57 \%(13 / 23)$ & 8 & 1 \\
\hline Withdrawal from social contacts & $43 \%(10 / 23)$ & $57 \%(13 / 23)$ & 7 & 2 \\
\hline Hyperactive child & $41 \%(9 / 22)$ & $59 \%(13 / 22)$ & 8 & 2 \\
\hline Problems with eye contact & $33 \%(8 / 24)$ & $67 \%(16 / 24)$ & - & 8 \\
\hline Tendency to isolate themselves from others & $22 \%(5 / 23)$ & $78 \%(18 / 23)$ & 7 & 2 \\
\hline Alarmingly weird behaviors & $18 \%(4 / 22)$ & $82 \%(18 / 22)$ & 6 & 4 \\
\hline Pica-type disorders & $13 \%(3 / 22)$ & $87 \%(19 / 22)$ & 7 & 3 \\
\hline Tics & $8 \%(2 / 24)$ & $92 \%(22 / 24)$ & 8 & - \\
\hline Stereotypies & $4 \%(1 / 23)$ & $96 \%(22 / 23)$ & 7 & 2 \\
\hline Self-destructive behaviors & $18 \%(4 / 22)$ & $82 \%(18 / 22)$ & 9 & 1 \\
\hline Negligence of personal hygiene & $19 \%(4 / 21)$ & $81 \%(17 / 21)$ & 9 & 2 \\
\hline Sad child & $8 \%(2 / 25)$ & $92 \%(23 / 25)$ & - & 7 \\
\hline Suicidal thoughts & $10 \%(2 / 19)$ & $90 \%(17 / 19)$ & 12 & 1 \\
\hline Suicidal attempts & $0 \%(0 / 18)$ & $100 \%(18 / 18)$ & 13 & 1 \\
\hline Bed-wetting & $9 \%(2 / 22)$ & $91 \%(20 / 22)$ & 9 & 1 \\
\hline Mutism & $0 \%(0 / 24)$ & $100 \%(24 / 24)$ & 7 & 1 \\
\hline Hallucinations or delusions & $0 \%(0 / 20)$ & $100 \%(20 / 20)$ & 12 & - \\
\hline
\end{tabular}

milestone. Four people did not remember examination results or failed to comment on the developmental diagnosis. The remaining 8 children ( $25 \%$ ) were never provided with professional psychological help. Currently, 2 out of 32 patients (only 6\%) are provided with psychological care. Two of the studied children had used psychiatric services.

\section{Discussion}

Genetic disorders affect not only the child's physical development, but also his/her emotional and social sphere. Parents who raise children with diagnosed genetic disorders not only have to face everyday problems, but also feel anxious about their current functioning and leading an adult life [14]. They wonder how their child will cope with daily duties, at first with learning, and in the future with work, and whether he/she will start a family. The incidence of 22q11DS is high and still underestimated. According to the latest statistics, it could occur in up to one per 2,000 live births, which is twice higher compared with generally published data [9]. It is worth mentioning that in some prenatal tests the incidence is even higher, i.e. it occurs in one per 1,000 pregnancies $[14,15]$. People affected by this disorder face a range of complex and diverse problems, so diagnosis could be hard and delayed. Hence, it is obvious that many authors point out a need to disseminate knowledge on this genetic syndrome, including among family and primary care doctors [15]. All chronic diseases, damage, malformations or developmental disturbances undoubtedly limit the social functioning of an individual. However, studies on this issue in patients with diagnosed 22q11DS have still not been conducted [11]. Polish studies, published on this issue, mostly focus on genetic disturbances and structural defects - mainly congenital disorders of the circulatory system. Only a few studies refer to immune disorders and psychiatric diseases which occur in patients with 22q11DS [3, 4, 6, 7, 16-18]. Studies which are published in in- ternational journals do not really present the situation of patients with the above syndrome in the Polish aspect $[19,20]$.

In our study we evaluate the problems which children with diagnosed 22q11DS have to deal with, in the subjective opinions given by the parents of these children. The parents had an opportunity to express their anxiety and fears by answering open-ended questions. All respondents with children older than one year ( $100 \%$ of this subgroup) pointed out problems with speech development. According to data gathered in the professional literature, difficulties in the areas of articulation and communication occur in $90 \%$ of children with 22q11DS [2, 21]. Characteristic features include: nasal speech due to velopharyngeal insufficiency, and delayed development of speech and language. Hearing disturbances, including impaired hearing, are equally serious problems negatively affecting speech development and functioning in children who complain of recurrent otitis media and secretory otitis media (in $75 \%$ of patients) and also sensorineural hearing loss (about $15 \%$ of patients usually suffer from unilateral mild or moderate perceptive hearing loss) [2]. Such children often speak unclearly, which might have a negative impact on their contacts with peers, which was seen in $47 \%$ of our patients. Speech problems might be a reason for the exclusion of such a child from a peer group. The results of some other studies conducted on children with 22q11DS revealed that such children often demonstrate an inability to develop normal speech, which affects their social functioning, as we found in our study $[2,21]$. Besides, speech underdevelopment might lead to another problem which parents report, i.e. shyness and withdrawal from contacts with others. If the children feel they are not understood, they may isolate themselves from others and not enter into relationships or launch initiatives, which will only exacerbate the problem.

The children included in the study also suffer from increased fear. This observation was also made in other published studies $[2,19,20]$. Their parents report that children are afraid 
of things, and phenomena which are noisy, e.g. cars, squeaking doors, helicopters, motorbikes, barking dogs, etc. This observation corresponds with those made by other researchers [20]. Almost half the children in our study $(43 \%$ who meet age criteria) demonstrate behavioral problems. The most common is obstinacy, but some children are more noisy and cannot control their anger. Withdrawal tendencies are probably caused by shyness and apprehension. These traits were mentioned before in literature and, as other authors suggest, they might intensify in older age $[19,20]$.

Similar to 22q11.2DS, Down syndrome may also be characterized by disturbances of speech development, caused by anomalies of the stomatognathic system. They occur in early childhood, and in school age memory disturbances appear. In older age a child might develop depression symptoms. Aggressive behavior and dementia, including early onset Alzheimer's disease, are quite common in this period [12]. More detailed data on social malfunctioning of children with 22q11DS and other genetic disorders are barely available. It is, however, widely known that observed disturbances in the studied children, such as avoiding eye contact, isolating themselves, self-destructive behavior, excessive apprehension (autism spectrum disorder affecting social functioning and inhibiting development), are also noted in fragile $X$ syndrome. Almost $100 \%$ of such patients demonstrate stereotypies, which occurred occasionally $(4 \%)$ in our study group. However, retarded speech development is observed equally often $[2,12]$.

The results of some studies indicate increased incidence of mood-related problems in patients with 22q11DS. However, in our study only parents of two children (8\%) reported that their children are excessively sad [2, 19, 20, 22, 23]. It should be pointed out that behavioral and psychiatric problems are common in such patients and, as statistics say, affect the functioning of about $93 \%$ of them [2]. Psychotic symptoms might occur in puberty, and the mean incidence of schizophrenia in such patients is significantly higher than in any other population. In one of the studies conducted on adult patients this incidence was as high as $24 \%$. The authors also stress that the incidence of this chromosomal abnormality in patients with a diagnosed mental illness is higher than in the general population (between 10 and 40 times!) $[2,6,22]$. It should, however, be stressed that only $75 \%$ of the studied children have ever been psychologically diagnosed, and no more than $6 \%$ in school age (and $21 \%$ in the total group) were provided with permanent psychological help. Such a situation might result from social awareness, which is still low, and scarce knowledge on a range of disturbances which accompany 22q11DS, as well as the difficulty patients and their family members have to deal with in various stages of the disease. It seems a serious problem because apart from the many difficulties such children face, they often deal with learning problems. In our study as many as $85 \%$ of children who meet age criteria experience that kind of difficulty. Some other studies indicate that such children demonstrate quite good memory and are able to memorize what they are supposed to learn. However, the ability to comprehend abstract ideas, particularly Mathematics, and also the ability to learn reading skills is quite poor $[2,7]$. Clumsiness and impaired movement coordination, concomitant with muscle hypotonia, so commonly observed in the majority of patients, have an impact on daily functioning and the development of gross and fine motor skills, which in turn affects writing skills and other manual skills. Due to complex school problems, most children have poor school performance and students require support in the learning process. Patients with 22q11DS are often regarded as people with mild mental disabilities, and the average IQ is around 70W [2]. Kok and Solman confirmed that the learning style of children with 22q11DS is analytical and organized, but such children are not really imaginative $[8,24]$. Despite the high incidence of $22 q 11$ deletion syndrome (the most common autosomal dele- tion and, according to the most recent data, the second - after Down syndrome - cause of intellectual disability), social awareness of this disorder and concomitant disturbances, as well as the knowledge of medical professionals, still seem to be insufficient. Professional medical personnel (specialists and primary care physicians), as well as pedagogists and psychologists working with children in kindergartens and schools, should improve their knowledge on this issue. A quick psychological diagnosis and evaluation of a child's psychomotor development might have a positive implication because the parents and doctors can initiate early supporting activities (e.g. with a psychologist, speech therapist and physiotherapist). Later on, a psychologist evaluates the child's intellectual development and potential emotional and cognitive problems. Together with parents, he/ /she implements learning methods, assists with development, and helps the child to deal with emotions. Thanks to such cooperation and immediate discussions on encountered problems, working out the best possible support methods for the child and his/her family is possible.

Due to the many disturbances which are concomitant with 22q11DS, the lifespan of patients with this disorder may be shorter. However, many people affected by 22q11DS live to a ripe old age. Being young adults, they not only become parents but may also experience 22q11.2 deletion syndromerelated problems, be socially excluded in daily life, and have difficulty obtaining specialist medical care. The parents of our two adult patients pointed out such problems. Adult 22q11DS patients also require professional care and support in their struggle with disability. Most patients with 22q11DS should be managed by a multidisciplinary team who have adequate knowledge, experience and attitude. It is essential to provide access to coordinated professional care throughout the whole therapy. This should be provided in compliance with recommendations and satisfy the needs of adults with 22q11DS, not only those regarding cardiac and mental problems, which, by the way, are the only problems that Polish researchers have been focused on up to now. Many recent foreign publications contain guidelines on satisfying the needs which patients with 22q11DS have in various stages of their life, and could also be helpful for family and primary care doctors $[2,5,25,26]$. However, there are still no studies on this issue in the professional literature in Poland.

22q11 Deletion Syndrome Awareness Day, celebrated annually in May all over the world, is an attempt made by those who are particularly interested in this disorder (medical specialists taking care of patients, parents of such patients who are members of various support groups, foundations, etc.). Such initiatives are aimed at disseminating knowledge, increasing social awareness and, for example, educating employees of health care systems and teachers. In Poland multidisciplinary care is still not sufficient, but recently the Association 22q11.2 Poland has been founded (find them on their website www.22q11.pl or on facebook - 22Q11 Polska, Zespół Di George'a, VCFS) to give support to families affected with this condition. It has been mentioned many times that this disease does not affect only small children. Due to medical advances, modern cardiosurgical techniques (providing 95\% survivability in patients under 1 year of age) and easy access to genetic tests, the disease is also commonly found in teenage children, young adults and adults [2, $25,26]$. As a result, the number of people affected by $22 q 11 D S$ is constantly increasing. According to estimates, the population of such patients in Poland might exceed 10,000, and annually around 100-200 children are born with 22q11DS, so every physician, including family doctors, should know how to recognize the syndrome, take care of these patients, know how to support their families, and also how important psychological care is, along with many others medical specialists. We believe that further studies on the functioning of microdeletion patients and their families in various stages of their life should be con- 
ducted as they will help to better identify problems, anomalies and needs. The small size of the study group and use of the authors' own questionnaire (face validity), which allowed us to obtain only subjective information on problems observed by our patients' parents in this pilot study, created many limitations. We hope that its results will be grounds for further, detailed, systematic and standardized studies, including comparative studies, which will compare other patients with chronic diseases, affected by different genetic and congenital anomalies, as well as properly selected control groups. Actually, we want to pay attention to the care of patients with 22q11DS and their relatives because, apart from disseminating knowledge on this issue, it is necessary to create multispecialist teams providing patients with organized, well-functioning care by implementing management standards in every stage of the patient's life (as has already been done in many countries all around the world), but the education of primary care doctors about the problems of these patients and their families seems to be the first step.

\section{Conclusions}

In conclusion, it is worth pointing out that the need to increase awareness of the psycho-social problems affecting patients with 22q11DS and their families, as the authors of many publications do, seems to be fully justified [14]. Implementing coordinated and adequate constant multispecialist medical care, including psychological care, in many cases life-long, also seems justified in the light of numerous problems that such patients and their relatives have to deal with, which was shown in our and many others studies [2, 5, 25, 26]. The child's health condition, in many parents' opinion, is a factor significantly influencing the psychosocial functioning in life, and determining the occurrence of problems in the future. The task of family physicians is to identify patients suspected of 22q11DS (based on the coexistence of several or many clinical features) and to lead them to genetic diagnostics, as well as to provide support to the patients and their family in different stages of life in cooperation with many other specialists.

Source of funding: The paper was developed using the university's funds (statute-based activity) and the authors' own funds. Conflicts of interest: The authors declare no conflicts of interest.

\section{References}

1. Lajiness-O'Neill RR. 22q11.2 deletion syndrome: introduction. Child Neuropsychol 2005; 11: 1-3.

2. Allgrove J, ed. Consensus Document on 22q11 Deletion Syndrome (22q11DS) MaxAppeal [cited 05.10.2016]. Available from URL: http://www.maxappeal.org.uk/downloads/Consensus_Document_on_22q11_Deletion_Syndrome.pdf.

3. Ziółkowska L, Kawalec W, Krajewska-Walasek M, et al. Zespół mikrodelecji 22q11.2 u noworodków z wadami wrodzonymi serca. Post Neonatol 2004; 2: 261-265 (in Polish).

4. Grygieńczo-Raźniewska E, Horodnicka-Józwa A, Wierzba J, et al. Współwystępowanie wad wrodzonych serca, rozszczepu podniebienia i innych cech dysmorficznych u dzieci jako przesłanka diagnostyczna poszukiwania zespołów delecji 22q11.2. Pediatr Pol 2007; 82: 300-307 (in Polish).

5. Bassett AS, McDonald-McGinn DM, Devriendt K, et al. Practical guidelines for managing patients with 22q11.2 deletion syndrome. J Pediatr 2011; 159: 332-339.

6. Pawłowska B, Tomankiewicz-Zawadzka A, Ilnicka A, et al. Badania nad występowaniem delecji 22q11.2 u osób z chorobą psychiczną. Psychiatr Pol 2007; 41: 251-260 (in Polish).

7. Dębicki S. Submikroskopowe rearanżacje chromosomowe jako przyczyna niepełnosprawności intelektualnej. Poznań: Uniwersytet Medyczny; 2012 (in Polish).

8. Kok LL, Solman RT. Velocardiofacial syndrome: learning difficulties and intervention. J Med Genet 1995; 32: 612-618.

9. Antshel KM, Kates WR, Roizen N, et al. 22q11.2 deletion syndrome: genetics, neuroanatomy and cognitive/behavioral features. Child Neuropsychol 2005; 11: 5-19.

10. Burnside RB. 22q11.21 deletion syndromes: a review of proximal, central, and distal deletions and their associated features. Cytogenet Genome Res 2015; 146: 89-99.

11. Zabłocki KJ, Brejnak W. Problemy rodzin z dzieckiem niepełnosprawnym. Kwartalnik Naukowy Fides et Ratio 2012; 1: 29-43 (in Polish).

12. Kulik M, Otrębski W. Funkcjonowanie rodziny z dzieckiem niepełnosprawnym w wyniku choroby genetycznej. Pol Forum Psychol 2012; 17: 91-104 (in Polish).

13. Jakuć O. Serce dziecka [cited 5.10.2016]. Available from URL: http://www.sercedziecka.org.pl/files/pdf/media/Rodzinadzieckazwadaserca.pdf (in Polish).

14. Sserunjogi GK. Haveing a child with velo-cardio-facial syndrome Family adaptation to the disability through changes in parents' belief systems in families of children with Velo-cardio-facial-syndrome in Norway. Oslo: University of Oslo; 2012.

15. Grati FR, Molina Gomes D, Ferreira JC, et al. Prevalence of recurrent pathogenic microdeletions and microduplications in over 9500 pregnancies. Prenat Diagn 2015; 35: 801-809.

16. Błońska AM. Genetyczne modyfikatory fenotypu kardiologicznego zespołu delecji 22q11. Wrocław: Uniwersytet Medyczny; 2015 (in Polish).

17. Grygieńczo-Raźniewska E, Studniak E, Zajączek S. Rodzicielskie uwarunkowania zespołów delecji 22q11.2. Pediatr Pol 2008; 83: 513-521 (in Polish).

18. Lewandowicz-Uszyńska A, Zwonarz K, Chmielarska J. The 22q11 microdeletion syndrome in children. Centr Eur J Immunol 2013; 38: 271-275.

19. Briegel W, Schneider M, Schwab KO. 22q11.2 deletion syndrome: behaviour problems of infants and parental stress. Child Care Health Dev 2007; 33: 319-324.

20. Briegel W, Schneider M, Schwab KO. 22q11.2 deletion syndrome: behaviour problems of children and adolescents and parental stress. Child Care Health Dev 2008; 34: 795-800.

21. D'Antonio LL, Scherer NJ, Miller LL, et al. Analysis of speech characteristics in children with velocardiofacial syndrome (VCFS) and children with phenotypic overlap without VCFS. Cleft Palate Craniofac J 2001; 38: 455-467.

22. Karayiorgou M, Morris MA, Morrow B, et al. Schizophrenia susceptibility associated with interstitial deletions of chromosome $22 q 11$. Proc Natl Acad Sci USA 1995; 92: 7612-7616.

23. Goldberg R, Motzkin B, Marion R, et al. Velo-cardio-facial syndrome: a review of 120 patients. Am J Med Genet 1993; 45: 313-319.

24. Lajiness-O'Neill RR, Beaulieu I, Titus JB, et al. Memory and Learning in children with 22q11.2 deletion syndrome: evidence for ventral and dorsal stream disruption? Child Neuropsychol 2005; 11: 55-71. 
25. Fung WL, Butcher NJ, Costain G, et al. Practical guidelines for managing adults with 22q11.2 deletion syndrome. Genet Med 2015; 17: 599-609.

26. Habel A, Herriot R, Kumararatne D, et al. Towards a safety net for management of 22q11.2 deletion syndrome: guidelines for our times. Eur J Pediatr 2014; 173: 757-765.

Tables: 2

Photographs: 2

References: 26

Received: 03.02.2017

Reviewed: 11.07 .2017

Accepted: 01.12.2017

Address for correspondence:

Agnieszka Cywińska-Bernas, MD PhD

Klinika Pediatrii, Immunologii i Nefrologii ICZMP

ul. Rzgowska 281/289

93-338 tódź

Polska

Tel.: +48 42 271-13-87

E-mail: a_bernas@o2.pl 